\title{
Evaluation of high nutrient diets on litter performance of heat-stressed lactating sows
}

\author{
Yohan Choi ${ }^{1}$, Abdolreza Hosseindoust ${ }^{1}$, YoungHo Shim², Minju Kim ${ }^{1}$, Alip Kumar ${ }^{1}$, Seungmin Oh', \\ YoungHwa Kim, and Byung-Jo Chae",
}

\begin{abstract}
* Corresponding Author: Byung-Jo Chae Tel: +82-33-250-8616, Fax: +82-33-259-5572, E-mail: bjchae@kangwon.ac.kr
\end{abstract}

'Department of Animal Resources Science, College of Animal Life Sciences, Kangwon National University, Chuncheon 24341, Korea

1685-18 Hamyeong-ro, Hampyeong-eup, Hampyeong 57136, Korea

${ }^{3}$ Department of Animal Resources Development Swine Science Division, RDA, Cheonan 31000, Korea

Submitted May 23, 2017; Revised Jul 4, 2017; Accepted Sept 12, 2017
Objective: The present study investigated the litter performance of multiparous sows fed $3 \%$ and $6 \%$ densified diets at farrowing to weaning during summer with mean maximum room temperature of $30.5^{\circ} \mathrm{C}$.

Methods: A total of 60 crossbred multiparous sows were allotted to one of three treatments based on body weight according to a completely randomized design. Three different nutrient levels based on NRC were applied as standard diet (ST; metabolizable energy, 3,300 kcal/kg), high nutrient level 1 (HE1; ST+3\% higher energy and 16.59\% protein) and high nutrient level 2 (HE2; ST $+6 \%$ higher energy and $17.04 \%$ protein).

Results: There was no variation in the body weight change. However, backfat thickness change tended to reduce in HE1 in comparison to ST treatment. Dietary treatments had no effects on feed intake, daily energy intake and weaning-to-estrus interval in lactating sows. Litter size, litter weight at weaning and average daily gain of piglets were significantly greater in sows in HE1 compared with ST, however, no difference was observed between HE2 and ST. Increasing the nutrient levels had no effects on the blood urea nitrogen, glucose, triglyceride, and creatinine at post-farrowing and weaning time. The concentration of follicle stimulating hormone, cortisol and insulin were not affected by dietary treatments either in post-farrowing or weaning time. The concentration of blood luteinizing hormone of sows in ST treatment was numerically less than sows in HE2 treatment at weaning. Milk and colostrum compositions such as protein, fat and lactose were not affected by the treatments.

Conclusion: An energy level of 3,400 kcal/ $\mathrm{kg}(14.23 \mathrm{MJ} / \mathrm{kg})$ with $166 \mathrm{~g} / \mathrm{kg}$ crude protein is suggested as the optimal level of dietary nutrients for heat stressed lactating sows with significant beneficial effects on litter size.

Keywords: Heat Stress; Lactating Sows; Litter Performance; Nutrient Densified Diet

\section{INTRODUCTION}

High ambient temperatures during lactation above the evaporative critical temperature (i.e., $\left.22^{\circ} \mathrm{C} ; 1\right)$, reduces average daily feed intake (ADFI) with negative consequences on farrowing rates and reproductive performance in lactating sows due to their high nutrient requirements $[1,2]$. The reduction in ADFI may be a natural mechanism to decrease metabolic heat production associated with digestion and metabolism [2-4]. This decreased voluntary intake leads to increased body reserves mobilization, increased weight loss at weaning, and reproductive performance of the lactating sows in subsequent parity as well [5]. However, the reduced weaning litter size and generally progeny growth because of decreased milk output may be an indirect effect associated with reducing the feed intake [6]. Appropriate management of lactating sows nutrition has been identified as a key determinant of productivity. The change in energy intake due to change in the diet energy density regulates feed intake. Therefore the total energy intake remains almost constant 
with lower ADFI in heat stress, even though the diets have different energy density.

In the current study, we considered the lowest protein level in the diet which was able to supply essential amino acids requirements. Several authors recommend reducing dietary protein levels in order to decrease heat increment and tissue loss, even though it has only a marginal benefit on litter size during heat stress [3]. It is important to ensure body protein mass preservation because the body protein mass can decrease weaning-to-estrus interval (WEI) and improve the subsequent litter size [7]. Therefore not only increasing energy intake but also a balanced dietary protein content need to be considered as an option in terms of decreasing tissue loss and improving weaning litter size.

The subsequent parity also can be affected by amplifying the inhibition of gonadotrophin releasing hormone and luteinizing hormone (LH) secretion in lactation, which prolongs the WEI [8]. In a previous study on the interaction between reproductive performance and heat stress in sows, the number of embryonic mortality significantly increased in sows exposed to heat [9]. The extra energy amount in the current study has been provided by the addition of fat to the diet. One of the first noticeable benefits of dietary fat is increased energy intake that presumably decreases the relative heat increment of feeding. The positive effects of dietary fat becomes even more apparent if its lower heat increment considers in digestion and metabolism processes [10,11]. Dietary fat increase caloric intake of heat stressed lactating sows due to high energy density [10], resulting the reduced body weight (BW) loss [12] and increased litter growth [13,14]. Improved litter weight may be expected if energy intake and milk output increase $[15,16]$. Other micronutrients also require to be balanced in the diet according to the increase in energy to avoid micronutrient deficiencies due to less feed intake in high thermal condition. Therefore micronutrients requires to be densely added to a high energy level diet to maintain the animal requirements. The NRC guidelines [17] have been considered as a reliable reference for sow requirements in temperature below $30^{\circ} \mathrm{C}$, however, they suggest a $7 \%$ to $25 \%$ increase in maintenance requirement during hot season [18]. From that point of view, although extensive productivity research has been conducted on lactating sows in tropical climate, little information is available on the effects of different energy levels based on the last issued NRC guidelines [17] concerning lactating sows exposed to heat. The NRC [17] is considered as a general standard in swine nutrition and it seems that the requirements need to change based on environmental condition.

The objectives of this experiment were to evaluate the influence of $3 \%$ and $6 \%$ densified diets on reproductive performance, ADFI, blood metabolites and milk composition of lactating sows in semi-hot ambient temperature.

\section{MATERIAL AND METHODS}

Animals and management
All sows used in this study were artificially inseminated 2 times after onset of estrus, and pregnancy was detected and confirmed at $\mathrm{d} 30$ post breeding using a Pharvision B-mode ultrasound machine (AV 2100V; Ambisea Tech. Corp, Shenzhen, China). All sows were placed in farrowing crates $(2.14 \times 2.15 \mathrm{~m})$ on $\mathrm{d} 109$ of gestation. Each crate had a single feeder, and water was always available through a nipple drinker. Heating pads for piglets were located on either side of the farrowing crates and maintained at $36^{\circ} \mathrm{C}$. Piglets were treated according to routine management practices that included teeth clipping, tail docking, ear notching, and subcutaneous iron dextran injections $(50 \mathrm{mg} / \mathrm{pig}$ ) within $24 \mathrm{~h}$. The feeders were checked 3 times per day to be refilled when required.

A total of sixty multiparous crossbred sows (Yorkshire $\times$ Landrace; average initial BW, $245.3 \mathrm{~kg}$ and 3.65 parity) were selected based on BW. Sows were divided into three treatments (20 sows/ treatment) on d 109 of gestation. The Three different nutrient levels were applied as: standard diet (ST), high nutrient level 1 (HE1; ST $+3 \%$ higher energy and $16.59 \%$ protein), and high nutrient level 2 (HE2; ST+6\% higher energy and $17.04 \%$ protein). Starting from the day after farrowing, the ration was gradually increased by one $\mathrm{kg}$ per day until maximum ration was reached ( $2 \mathrm{~kg}+0.6 \mathrm{~kg}$ per piglet) about seven days post-partum. Unconsumed feed was weighed daily to determine actual feed intake. All the sows were fed a common corn-soybean meal based diet as per NRC [17] requirements for lactation (Table 1). The average minimum and maximum ambient temperatures observed in the conventional farrowing rooms $\left(24.5^{\circ} \mathrm{C} \pm 3.7^{\circ} \mathrm{C}\right.$ and $30.5^{\circ} \mathrm{C}$ $\pm 3.6^{\circ} \mathrm{C}$ ) frequently exceeded $24^{\circ} \mathrm{C}$.

\section{Measurements and data collection}

Live weight was measured on $\mathrm{d} 109$ (pre-farrowing) during gestation, and d 24 (weaning) during lactation. Sow backfat thickness at the 10th rib was monitored at $\mathrm{d} 109$ of gestation, and at weaning (d 24 \pm 1 of lactation) using an ultrasonic device (Agroscan A16, Angouleme, France). Changes in backfat thickness of sows during lactation were estimated by calculating the difference between backfat thicknesses at $\mathrm{d} 109$ of gestation and backfat thickness at d 24 of lactation. Standard litter traits such as number born and born alive, BW $(\mathrm{kg})$ at birth and weaning, and numbers weaned were detected. Feed intake $(\mathrm{kg} / \mathrm{d})$ of each sow and WEI (d) were also recorded. The value of average daily gain (ADG) of piglets was calculated by final BW minus the first BW divided by weaning date (d) multiplied by the number of weaned piglets.

\section{Blood metabolites}

On days 1 (post-farrowing) and 24 (weaning, after piglet removal) of lactation, a $10-\mathrm{mL}$ blood sample was collected by jugular vein puncture from all the sows between 0830 and 0930 using a disposable vacutainer tube without anticoagulant (Becton Dickinson, Franklin, NJ, USA). After centrifugation $(3,000 \times \mathrm{g}$ for $15 \mathrm{~min}$ at $4^{\circ} \mathrm{C}$ ), serum samples were separated and stored at $-20^{\circ} \mathrm{C}$ and 
Table 1. Formula and chemical composition of lactation sow diets (as-fed basis)

\begin{tabular}{|c|c|c|c|}
\hline Treatments & $\mathrm{ST}^{1)}$ & $\mathrm{HE} 1^{1)}$ & HE2 $^{1)}$ \\
\hline \multicolumn{4}{|l|}{ Ingredients (g/kg) } \\
\hline Corn & 620.45 & 581.0 & 541.4 \\
\hline Wheat & 50.0 & 50.0 & 50.0 \\
\hline Soybean meal & 222.2 & 239.7 & 257.1 \\
\hline Animal fat & 31.0 & 52.2 & 73.6 \\
\hline Molasses & 30.0 & 30.0 & 30.0 \\
\hline L-lysine·HCl (78\%) & 2.83 & 2.67 & 2.52 \\
\hline DL-methionine (88\%) & 0.72 & 0.78 & 0.82 \\
\hline L-threonine $(98.5 \%)$ & 1.28 & 1.26 & 1.27 \\
\hline L-tryptophan (10\%) & 4.37 & 4.07 & 3.90 \\
\hline L-valine $(98.5 \%)$ & 1.95 & 1.99 & 2.05 \\
\hline Choline chloride (50\%) & 0.50 & 0.51 & 0.53 \\
\hline Limestone & 6.0 & 6.37 & 6.51 \\
\hline Tricalcium phosphate & 20.2 & 20.7 & 21.3 \\
\hline Salt & 5.00 & 5.15 & 5.30 \\
\hline Vitamin premix ${ }^{2)}$ & 1.50 & 1.55 & 1.60 \\
\hline Mineral premix ${ }^{3)}$ & 1.50 & 1.55 & 1.60 \\
\hline Phytase & 0.50 & 0.50 & 0.50 \\
\hline Total & 1,000 & 1,000 & 1,000 \\
\hline \multicolumn{4}{|l|}{ Calculated composition ( $/ \mathrm{kg}$ ) } \\
\hline $\mathrm{ME}(\mathrm{kcal} / \mathrm{kg})$ & 3,300 & 3,400 & 3,500 \\
\hline Crude protein & 161.5 & 165.9 & 170.4 \\
\hline Calcium & 9.10 & 9.40 & 9.70 \\
\hline Available phosphorus & 4.60 & 4.70 & 4.80 \\
\hline SID. Arginine & 8.58 & 9.00 & 9.39 \\
\hline SID. Histidine & 3.50 & 3.61 & 3.71 \\
\hline SID. Isoleucine & 5.25 & 5.47 & 5.67 \\
\hline SID. Leucine & 12.13 & 12.31 & 12.47 \\
\hline SID. Lysine & 9.10 & 9.37 & 9.65 \\
\hline SID. Methionine & 2.66 & 2.76 & 2.85 \\
\hline SID. Methionine+cysteine & 4.90 & 5.05 & 5.19 \\
\hline SID. Threonine & 5.80 & 5.97 & 6.15 \\
\hline SID. Tryptophan & 1.80 & 1.85 & 1.91 \\
\hline SID. Valine & 7.70 & 7.93 & 8.16 \\
\hline
\end{tabular}

SID, standardized ileal digestibility; ME, metabolizable energy.

1) ST, standard diet; HE1, high nutrient level 1, ST+3\% higher energy and 16.59\% protein; HE2, high nutrient level 2, ST+6\% higher energy and $17.04 \%$ protein.

2) Supplied per kilogram of vitamin premix: 7,000,000 IU vitamin A, 2,400,000 IU vitamin $D_{3}, 132,000$ IU vitamin $E_{1} 1,500$ mg vitamin $K_{3}, 3,000$ mg vitamin $B_{1}, 11,250$ mg vitamin $B_{2}, 3,000$ mg vitamin $B_{6}, 60$ mg vitamin $B_{12}, 36,000$ mg pantothenic acid, $30,000 \mathrm{mg}$ niacin, $600 \mathrm{mg}$ biotin, 4,000 $\mathrm{mg}$ folic acid.

${ }^{3)}$ Supplied per kilogram of mineral premix: 80,000 mg Fe, $170 \mathrm{mg} \mathrm{Co,} \mathrm{8,500} \mathrm{mg} \mathrm{Cu,}$ 25,000 mg Mn, 95,000 mg Zn, 140 mg I, 150 mg Se.

later analyzed for blood metabolites (triglyceride, blood urea nitrogen, glucose, and creatinine) and insulin. Commercial kits (Fujifilm Corp., Saitama, Japan) were used for analysis of blood metabolites using an automated chemistry analyzer (Fuji Drichem 3500i, Fujifilm Corp., Japan).

\section{Hormones}

On day 1 (post farrowing), and day 24 (weanling, after piglet removal) of lactation, $10-\mathrm{mL}$ blood samples were collected before feeding (before 0900) at 60-min intervals for $4 \mathrm{~h}$ from 0900 to 1300 for analysis of follicle stimulating hormone (FSH), LH, cortisol and insulin. Swine LH, FSH, cortisol, and insulin kits (Endocrine Technologies Inc., Newark, CA, USA) were used and their concentrations were determined in duplicate by enzymelinked immunosorbent assay using Biolog MicroStation system.

\section{Colostrum and milk composition}

Approximately $25 \mathrm{~mL}$ of colostrum and milk samples were manually collected from each sow on days 1 and 10 postpartum respectively to evaluate their composition. Sows were given $1 \mathrm{~mL}$ of oxytocin $(1 \mathrm{U} / \mathrm{mL})$ intravenously to stimulate milk release. Milk was manually collected from all functional teats after alcohol swabbing. Milk samples were immediately frozen at $-20^{\circ} \mathrm{C}$ and analyzed using an infrared milk analyzer (Milko Scan 133B. Analyser; Foss Electric, Hillerød, Denmark).

\section{Statistical analyses}

Data generated in the present study was subjected to statistical analysis using the general linear model procedure of SAS package [19] (SAS Inst. Inc., Cary, NC, USA) in a complete block design. When significant difference were identified among treatment means, they were separated using Tukey's honestly significant difference test. Individual sow was used as experimental unit for analysis of all variables. Probability values of $\leq 0.05$ were considered significant in both experiments.

\section{RESULTS}

\section{Sow and litter performance}

The effects of dietary nutrient levels on sow reproductive performance are shown in Table 2, 3. There was no variation in the BW at farrowing and weaning, BW change during lactation, and backfat change during lactation, however, the backfat thickness change was tended to reduce $(\mathrm{p}=0.09)$ in HE1 in comparison to ST treatment. Dietary treatments had no effects on ADFI, daily energy intake and WEI of the sows. Mean initial litter size, initial litter weight, number of weaned piglets and survivability were not different $(\mathrm{p}>0.05)$ in the three nutrient levels, whereas final weaning weight tended to increase $(\mathrm{p}=0.10)$ by $9 \%$ in sows in HE1 compared with ST. Sows in HE1 treatment presented the greatest weaning weight per piglet $(\mathrm{p}<0.05)$. Moreover, total weight gain at weaning was tended to increase in HE1 $(49.83,56.21$, and 53.05 for ST, HE1, and HE2, respectively). The average weight gain was higher $(12.2 \%, \mathrm{p}<0.05)$ when sows were received HE1 diet than ST diet.

\section{Blood metabolites}

Blood metabolites data are presented in Table 4. Increasing the nutrient levels had no effect on the blood metabolites (Blood urea nitrogen, glucose, triglycerides, and creatinine) at post-farrowing and weaning. However, the concentration of triglycerides, and creatinine were higher at post-farrowing than weaning. 
Table 2. Effects of different nutrient levels on backfat thickness changes, feed intake and weaning to estrus interval in sows during summer season

\begin{tabular}{|c|c|c|c|c|c|}
\hline Items & $\mathrm{ST}^{1)}$ & HE $1^{1)}$ & HE2 $2^{1)}$ & SEM & $\mathrm{p}$-value \\
\hline Parity & 3.65 & 3.60 & 3.70 & 0.29 & 0.971 \\
\hline \multicolumn{6}{|l|}{ Sow body weight (kg) } \\
\hline Gestation, d 109 & 242.4 & 238.7 & 239.4 & 4.70 & 0.838 \\
\hline Weaning (24 d old) & 218.5 & 219.1 & 218.7 & 3.87 & 0.995 \\
\hline Body weight change & -23.93 & -19.64 & -20.67 & 1.49 & 0.119 \\
\hline \multicolumn{6}{|l|}{ Sow Backfat thickness (mm) } \\
\hline Backfat thickness change & -4.90 & -3.95 & -4.22 & 0.31 & 0.093 \\
\hline Daily feed intake (kg/d) & 5.04 & 5.19 & 4.91 & 0.14 & 0.395 \\
\hline Daily ME intake (Mcal/d) & 16.64 & 17.66 & 17.20 & 0.48 & 0.342 \\
\hline Weaning-to-estrus interval (d) & 5.05 & 4.75 & 4.85 & 0.32 & 0.798 \\
\hline
\end{tabular}

SEM, standard error of means; $M E$, metabolizable energy.

1) ST, standard diet, NRC [19]; HE1, high nutrient level 1, ST+3\% higher energy and $16.59 \%$ protein; HE2, high nutrient level 2, ST+6\% higher energy and $17.04 \%$ protein.

Table 3. Effects of different nutrient levels on litter size and piglet performance in sows during summer season

\begin{tabular}{|c|c|c|c|c|c|}
\hline Items & $\mathrm{ST}^{1)}$ & HE1 ${ }^{1)}$ & HE2 ${ }^{1)}$ & SEM & $\mathrm{p}$-value \\
\hline \multicolumn{6}{|l|}{ Litter size } \\
\hline Initial litter size & 10.39 & 10.22 & 10.21 & 0.24 & 0.851 \\
\hline Piglets weaned & 9.94 & 9.98 & 9.67 & 0.21 & 0.557 \\
\hline Survivability (\%) & 95.94 & 97.91 & 94.98 & 1.92 & 0.586 \\
\hline \multicolumn{6}{|l|}{ Litter weight (kg) } \\
\hline Initial (1 d old) & 16.51 & 15.88 & 15.59 & 0.42 & 0.298 \\
\hline Initial, kg/pig (1 d old) & 1.59 & 1.56 & 1.54 & 0.04 & 0.521 \\
\hline Weaning ( $24 \mathrm{~d}$ old) & 66.34 & 72.09 & 68.65 & 1.84 & 0.099 \\
\hline Weaning weight kg/pig (24 d old) & $6.68^{b}$ & $7.28^{\mathrm{a}}$ & $7.10^{\mathrm{ab}}$ & 0.16 & 0.035 \\
\hline Total weight gain & 49.83 & 56.21 & 53.05 & 1.78 & 0.055 \\
\hline Average weight gain (g/pig) & $203.6^{b}$ & $228.6^{\mathrm{a}}$ & $222.8^{\mathrm{ab}}$ & 6.71 & 0.032 \\
\hline
\end{tabular}

SEM, standard error of means.

1) ST, standard diet, NRC [19]; HE1, high nutrient level 1, ST+3\% higher energy and $16.59 \%$ protein; HE2, high nutrient level $2, \mathrm{ST}+6 \%$ higher energy and $17.04 \%$ protein.

${ }^{a b}$ Values with different superscripts of the row significantly differ $(p<0.05)$.

\section{Hormone profiles}

Regarding the insignificant trend of blood hormones among the

Table 4. Effects of different nutrient levels on blood metabolites of lactating sows during summer season

\begin{tabular}{lccccc}
\hline Items & ST $^{1)}$ & HE1 $^{1)}$ & HE2 $^{1)}$ & SEM & p-value \\
\hline $\begin{array}{l}\text { Blood urea nitrogen (mmol/L) } \\
\quad \text { Post farrowing }\end{array}$ & 5.1 & 5.72 & 5.75 & 0.31 & 0.986 \\
$\quad$ Weanling 24 d & 6.04 & 6.42 & 6.48 & 0.25 & 0.371 \\
$\begin{array}{l}\text { Glucose (mmol/L) } \\
\quad \text { Post farrowing }\end{array}$ & 5.11 & 5.06 & 5.08 & 0.212 & 0.962 \\
$\quad$ Weanling (24 d old) & 5.13 & 5.04 & 4.95 & 0.22 & 0.823 \\
$\begin{array}{l}\text { Triglyceride (mmol/L) } \\
\quad \text { Post farrowing }\end{array}$ & 0.63 & 0.62 & 0.62 & 0.03 & 0.939 \\
$\quad$ Weanling (24 d old) & 0.3 & 0.33 & 0.34 & 0.02 & 0.213 \\
Creatinine (mmol/L)* & & & & & \\
$\quad$ Post farrowing & 0.18 & 0.181 & 0.185 & 0.005 & 0.876 \\
$\quad$ Weanling (24 d old) & 0.166 & 0.155 & 0.153 & 0.006 & 0.391 \\
\hline
\end{tabular}

SEM, standard error of means.

1) ST, standard diet, NRC [19]; HE1, high nutrient level 1, ST+3\% higher energy and $16.59 \%$ protein; HE2, high nutrient level 2, ST+6\% higher energy and $17.04 \%$ protein.

* Significant difference in values between post farrowing and weanling $(p<0.05)$. treatments, the average of 5 blood samples were applied for statistical analysis. The concentration of FSH, cortisol, and insulin were not affected by dietary treatments either in post farrowing or weaning period (Table 5). The concentration of blood LH at weaning was numerically lower in sows in ST than sows in HE2 ( $0.61 \mathrm{vs} 0.68 \mathrm{ng} / \mathrm{mL} ; \mathrm{p}=0.10$ ). All hormone biochemistry analyses showed the effect of sampling time (post farrowing and weaning) on hormone levels. The blood concentration of LH and FSH were increased $(\mathrm{p}<0.05)$ at weaning, whereas insulin and cortisol levels were decreased at weaning.

\section{Colostrum and milk composition}

As presented in Table 6, milk and colostrum compositions such as protein, fat and lactose were not affected by the treatments.

\section{DISCUSSION}

The results of BW, as well as changes in backfat thickness obtained in our study, were not affected by the different nutrient density. Although nutrient levels in increased ambient tempera- 
Table 5. Effects of different nutrient level on hormone profiles of lactating sows during summer season

\begin{tabular}{lccccc}
\hline Items & ST $^{1)}$ & HE1 $^{1)}$ & HE2 $^{1)}$ & SEM & p-value \\
\hline FSH (nmol/L)* & & & & & \\
$\quad$ Post farrowing & 6.55 & 6.52 & 6.49 & 0.13 & 0.892 \\
$\quad$ Weanling (24 d old) & 9.60 & 9.82 & 9.89 & 0.10 & 0.204 \\
LH (nmol/L)* & & & & & \\
$\quad$ Post farrowing & 1.68 & 1.62 & 1.56 & 0.06 & 0.217 \\
$\quad$ Weanling (24 d old) & 1.94 & 2.07 & 2.16 & 0.06 & 0.098 \\
Cortisol (nmol/L) & & & & & \\
$\quad$ Post farrowing & 17.51 & 16.66 & 17.05 & 1.20 & 0.879 \\
$\quad$ Weanling (24 d old) & 12.41 & 11.83 & 11.39 & 0.56 & 0.444 \\
Insulin (pmol/L)* & & & & & \\
$\quad$ Post farrowing & 143.1 & 141.9 & 145.6 & 6.31 & 0.913 \\
$\quad$ Weanling (24 d old) & 121.1 & 125.4 & 128.2 & 4.39 & 0.538 \\
\hline
\end{tabular}

SEM, standard error of means; FSH, follicle stimulating hormone; LH, luteinizing hormone.

1) ST, standard diet, NRC [19]; HE1, high nutrient level 1, ST+3\% higher energy and $16.59 \%$ protein; HE2, high nutrient level 2, ST+6\% higher energy and $17.04 \%$ protein. * Significant difference in values between post farrowing and weanling $(p<0.05)$.

ture in the present study did not influence the total energy intake, it did numerically decrease the backfat loss. A beneficial outcome of feeding sows diets supplemented with fat has been observed in heat stress [6]. The potential benefits of supplementing fat contributed to the greater energy intake and low heat increment in sows [11], which is especially beneficial when sows are experiencing heat stress. The loss of body reserve during lactation in sows is attributed to limited feed intake [7], which may improve by increasing diet energy level with supplementing fat. The insignificant BW change in the current study was similar to Rosero et al [20] who reported that BW at placement, farrowing and weaning was not affected by either $2 \%$ or $4 \%$ and $6 \%$ inclusion of animal-vegetable blend fat in lactating sows. However, they reported a linear backfat loss by decreasing dietary fat level.

The results of changes in ADFI obtained in our study, were not affected by the energy levels. It is generally documented that

Table 6. Effects of different nutrient levels on colostrum and milk composition of lactating sows during summer season

\begin{tabular}{lccccc}
\hline Items & ST $^{\text {1) }}$ & HE1 $^{\mathbf{1}^{\mathbf{}}}$ & HE2 $^{{ }^{1)}}$ & SEM & p-value \\
\hline Colostrum (\%) & & & & & \\
$\quad$ Total solid & 22.51 & 22.41 & 22.71 & 0.64 & 0.945 \\
$\quad$ Protein & 15.55 & 15.39 & 15.79 & 0.51 & 0.860 \\
Fat & 5.54 & 5.43 & 5.65 & 0.21 & 0.759 \\
$\quad$ Lactose & 3.65 & 3.61 & 3.73 & 0.16 & 0.881 \\
Milk (\%) (10 d postpartum) & & & & \\
$\quad$ Total solid & 17.43 & 18.38 & 18.73 & 0.67 & 0.396 \\
Protein & 5.69 & 6.03 & 6.16 & 0.17 & 0.151 \\
Fat & 7.14 & 7.59 & 7.74 & 0.30 & 0.358 \\
Lactose & 5.20 & 5.56 & 5.79 & 0.20 & 0.149 \\
\hline
\end{tabular}

SEM, standard error of means.

1) ST, standard diet, NRC [19]; HE1, high nutrient level 1, ST+3\% higher energy and

$16.59 \%$ protein; HE2, high nutrient level 2, ST+6\% higher energy and $17.04 \%$ protein.
ADFI of lactating sows is not adequate to cover nutrient requirements of maintenance, body growth and milk production [4]. However, we did not detect significant differences in energy intake, there was a numerical tendency for a greater total energy intake. Insignificant results might be attributed to low number of sows, which was only 20 sows per group. Muns et al [2] found significant differences on backfat thickness when the number of sows were over than 30 sows per treatment. The total ADFI in a high energy level diet may decrease but the total energy intake increase [11]. O'Grady et al [10] demonstrated that supplementation of fat to lactating sow diets increased the caloric intake in hot environment. Several authors recommend increasing energy density [3,21] affect sow feed intake and litter performance during hot weather. Even the same energy intake in fat supplemented diet may be more beneficial in heat stress condition because of lower total heat increment. The discrepancy between the results of current study may be explained by the imposed heat stress condition that was only $25^{\circ} \mathrm{C}$, whereas the temperature in the study of Rosero et al [20] was a higher average temperature $\left(25^{\circ} \mathrm{C}\right)$, and also sows were exposed to higher temperature $\left(29^{\circ} \mathrm{C}\right)$ in the work of Renaudeau et al [3]. Silva et al [22] reported that ADFI of lactating sows were significantly lower in hot environment $\left(26.1^{\circ} \mathrm{C}\right)$ compared with warm environment $\left(23.7^{\circ} \mathrm{C}\right)$. The amount of feed intake determine the value of produced heat from digestion and metabolism process $[4,23]$. It seems that a dense diet in a chronic semi-hot environment cannot be as effective as hot environment. Recently, few studies have investigated the benefits of diet dense manipulation based on new requirement standards in semi-hot environment of sows.

There has been an increase in litter size in modern sows over the last years [24]. Therefore, there is a greater demand for milk production, which may be supported by the diet and operating advanced feeding programs to ensure optimal nutrients requirements. The ADG of piglets was lower in ST, nevertheless the body fat mobilization tended to be greater in lactating sows in ST group. A possible explanation for our finding is that the efficiency of received energy from the feed is higher than energy mobilized from body reserve during heat stress. Lauridsen and Danielsen [25] reported a $19 \%$ increased litter weight in sows fed $8 \%$ of animal fat, coconut oil, palm oil, or sunflower oil than sows without supplementary fat. Another experiment confirmed that both medium-chain triglycerides and choice white grease increased a $6 \%$ litter growth performance when adding $10 \%$ in the diet [15]. The higher energy intake in sows enhanced litter growth by increasing milk production $[15,16]$. Rosero et al [20] reported that supplementation of a mix of animal and vegetable increased litter weight at weaning only in multiparous sows and it could not affect the performance of sows in their first parity. On the other hand, the high levels of dietary fat (Above 5.6\%) severely decrease pellet durability and increase fines in the diet [26], which can decrease the feed physical quality and marketability. Regarding the greater ADG of piglets, it seems that the additional energy supplied in 
the current experiment was not applied for sow BW or backfat, but probably stimulated mammary glands to increase the output of milk. Therefore, from a practical perspective, the supplemented fat in multiparous sows diet seems more important to maintain the requirement due to the greater body reserve mobilization, litter size and milk output.

The concentration of blood triglyceride increased after farrowing and then declined at the end of lactation. The increase in triglyceride after farrowing suggests that the sows were mobilizing energy for milk production due to low feed intake. As lactation progressed, the decrease in triglyceride concentrations might be due to less body fat mobilization in a more positive energy balance. A more positive energy balance at weaning may decrease body reserve mobilization, consequently showing lower protein degradation and blood creatinine levels. High concentrations of creatinine in the plasma is considered an indicator of negative energy balance and excess catabolism of lean body mass [27]. This difference in body energy balance and amount of feed, together with the environmental factors, probably resulted in the discrepancies between post farrowing and weaning.

Different authors have observed that sows exposed to hot environment would be more in negative energy balance and return to estrus with delay due to decrease in releasing of LH [28]. It has been confirmed that the subsequent reproductive performance and WEI interval can be affected by the amount of body reserve mobilization in lactation period [29]. Therefore, it shows the importance of a balanced diet, particularly in high-producing lactating sow when heat stressed, to meet the nutrient requirements of lactating sows in order to reduce body tissue loss, increase milk output, which finally may result a greater reproductive performance.

Research investigating the effect of energy levels on the mammary gland uptake and milk composition of lactating sows in hot environment is very limited. In agreement with Renaudeau and Noblet [21] and Silva et al [22], our results showed no effects on protein, fat, lactose, or total solid content of milk in sows exposed to hot climatic conditions. On the other hand, Boyd et al [15] reported that the increasing dietary fat increases the milk fat content as well. Considering the similar milk composition, it may be hypothesized that the output of milk can be the reason for the greater piglets' daily gain in the hot environment, as earlier studies also reported the greater milk production positively affect the litter weight in sows [30].

Lactating sows fed high density diet in the hot environment had a tendency for elevated levels of plasma LH compared with sows lactating in ST. Increasing LH secretion and follicular growth may have contributed to feed intake, since energy received through feeding has a significant effect on increasing LH [31]. The reduced LH secretion at elevated temperatures decreases follicle growth in lactation period and restrict follicle development after lactation [8]. Our study showed an insignificant effect of energy levels on weaning to estrus interval, whereby the sows fed high energy tended to have a greater blood LH. The diminished secretion of $\mathrm{LH}$ and increased the rate of postweaning anestrus occur when the mobilization of protein increased in lactating sows [32]. According to Flowers et al [33], increase in ambient temperature negatively influence the return to estrus of sows after weaning by decreased secretion of LH. Therefore, the tendency in a greater LH in high energy diets may refer to less negative energy balance. However, the total energy intake were not significantly different between groups, the efficiency of high fat diets might be greater due to less heat increment of high fat diet. Although the WEI duration was not different among the groups.

\section{CONCLUSION}

In conclusion, the present study demonstrates that the use of HE1 diet (3,400 kcal/kg metabolizable energy [ME] and $166 \mathrm{~g} / \mathrm{kg}$ crude protein $(\mathrm{CP})$ in lactation improves litter growth and tended to decrease the negative effects of high ambient temperature on backfat thickness change compared with ST diet $(3,300 \mathrm{kcal} / \mathrm{kg}$ $\mathrm{ME}$ and $161 \mathrm{~g} / \mathrm{kg} \mathrm{CP})$. However, HE2 diet $(3,500 \mathrm{kcal} / \mathrm{kg}$ and $170 \mathrm{~g} / \mathrm{kg} \mathrm{CP}$ ) was not able to improve litter performance of lactating sows.

\section{CONFLICT OF INTEREST}

We certify that there is no conflict of interest with any financial organization regarding the material discussed in the manuscript.

\section{ACKNOWLEDGMENTS}

This work was carried out with the support of Cooperative Research Program for Agriculture Science and Technology Development (Project No. 01160302), Rural Development Administration, Republic of Korea. The authors are thankful to the Institute of Animal Resources, Kangwon National University, Chuncheon, Republic of Korea for providing the technical facilities to conduct this experiment.

\section{REFERENCES}

1. Quiniou N, Noblet J. Influence of high ambient temperatures on performance of multiparous lactating sows. J Anim Sci 1999;77: 2124-34.

2. Muns R, Manzanilla EG, Manteca X, Gasa J. Effect of gestation management system on gilt and piglet performance. Anim Welf 2014;23: 343-51.

3. Renaudeau D, Quiniou N, Noblet J. Effects of exposure to high ambient temperature and dietary protein level on performance of multiparous lactating sows. J Anim Sci 2001;79:1240-9.

4. Williams AM, Safranski TJ, Spiers DE, et al. Effects of a controlled heat stress during late gestation, lactation, and after weaning on thermoregulation, metabolism, and reproduction of primiparous sows. 
J Anim Sci 2013;91:2700-14.

5. Dourmad JY, Noblet J, Etienne M. Effect of protein and lysine supply on performance, nitrogen balance, and body composition changes of sows during lactation. J Anim Sci 1998;76:542-50.

6. Spencer J D, Boyd RD, Cabrera R, Allee GL. Early-weaning to reduce tissue mobilization in lactating sows and provision of milk replacement to enhance pig wean weight during extreme heat stress. J Anim Sci 2003;81:2041-52.

7. Boyd RD, Touchette KJ, Castro GC, et al. Recent advances in amino acid and energy nutrition of prolific sows-review. Asian-Australas J Anim Sci 2000;13:1638-52.

8. Kong LJ, Wang AG, Fu JL, et al. Peroxisome proliferator-activated receptor gamma is involved in weaning to estrus of primiparous sows by regulating the expression of hormone genes in hypothalamuspituitary-ovary axis. Asian-Australas J Anim Sci 2007;20:340-50.

9. Omtvedt IT, Nelson RE, Edwards RL, Stephens DF, Turman EJ. Influence of heat stress during early, mid and late pregnancy of gilts. J Anim Sci 1971;32:312-7.

10. O’Grady JF, Lynch PB, Kearney PA. Voluntary feed intake by lactating sows. Livest Prod Sci 1985;12:355-65.

11. Pettigrew JE, Moser RL. Fat in swine nutrition. In: Miller ER, Ullrey DE, Lewis AJ, editors. Boston, MA, USA: Butterworth-Heinemann; 1991. pp. 133-45.

12. Stahly TS, Cromwell GL, Simpson WS. Effects of level and source of supplemental fat in the lactation diet of sows on the performance of pigs from birth to market weight. J Anim Sci 1980;51:352-60.

13. Averette LA, Odle J, Monaco MH, Donovan SM. Dietary fat during pregnancy and lactation increases milk fat and insulin-like growth factor I concentrations and improves neonatal growth rates in swine. J Nutr 1999;129:2123-9.

14. Averette Gatlin LA, Odle J, Soede J, Hansen JA. Dietary mediumor long- chain triglycerides improve body condition of lean-genotype sows and increase suckling pig growth. J Anim Sci 2002;80:38-44.

15. Boyd RD, Moser BD, Peo ER, Lewis AJ, Johnson RK. Effect of tallow and choline chloride addition to the diet of sows milk composition, milk yield and preweaning pig performance. J Anim Sci 1982;54:1-7.

16. Cieslak DG, Leibbrandt VD, Benevenga NJ. Effect of a high fat supplement in late gestation and lactation on piglet survival and performance. J Anim Sci 1983;57:954-9.

17. NRC. Nutrient requirements of swine. 11th ed. Washington, DC: Natl Acad Press; 2012.

18. Baumgard LH, Rhoads JRP. Effects of heat stress on postabsorptive metabolism and energetics. Annu Rev Anim Biosci 2013;1:311-37.
19. SAS. Statistical Analysis System. Users Guide: Statistics, Version 8.2, Cary, NC, USA: SAS Institute; 2012.

20. Rosero DS, Van Heugten E, Odle J, et al. Sow and litter response to supplemental dietary fat in lactation diets during high ambient temperatures. J Anim Sci 2012;90:550-9.

21. Renaudeau D, Noblet J. Effects of exposure to high ambient temperature and dietary protein level on sow milk production and performance of piglets. J Anim Sci 2001;79:1540-8.

22. Silva BAN, Noblet J, Donzele JL, et al. Effects of dietary protein level and amino acid supplementation on performance of mixed-parity lactating sows in a tropical humid climate. J Anim Sci 2009;87:4003-12.

23. Renaudeau D, Collin A, Yahav S, et al. Adaptation to hot climate and strategies to alleviate heat stress in livestock production. Animal 2012;6:707-28.

24. Stadler KJ. Pork industry productivity analysis. Des Moines, IA, USA: National Pork Board; 2013.

25. Lauridsen C, Danielsen V. Lactational dietary fat levels and sources influence milk composition and performance of sows and their progeny. Livest Prod Sci 2004;91:95-105.

26. Briggs JL, Maier DE, Watkins BA, Behnke KC. Effect of ingredients and processing parameters on pellet quality. Poult Sci 1999;78:1464-71.

27. DeRouchey JM, Hancock JD, Hines RH, et al. Effects of dietary electrolyte balance on the chemistry of blood and urine in lactating sows and sow litter performance. J Anim Sci 2003;81:3067-74.

28. Van den Brand H, Heetkamp MJW, Soede NM, Schrama JW, Kemp B. Energy balance of lactating primiparous sows as affected by feeding level and dietary energy source. J Anim Sci 2000;78:1520-8.

29. Tritton SM, King RH, Cambell RG, Edwards AC, Hughes PE. The effects of dietary protein and energy levels of diets offered during lactation on the lactational and subsequent reproductive performance of first-litter sows. Anim Sci 1996;62:573-9.

30. Strathe AV, Bruun TS, Hansen CF. Sows with high milk production had both a high feed intake and high body mobilization. Animal 2017;15:1-9.

31. Kemp B, Soede NM. Should weaning be the start of the reproductive cycle in hyper-prolific cows? A physiological view. Reprod Domest Anim 2012;47:320-6.

32. King RH, Martin GB. Relationships between protein intake during lactation, LH levels and oestrous activity in first-litter sows. Anim Reprod Sci 1989;19:283-92.

33. Flowers B, Day BN. Alterations in gonadotropin secretion and ovarian function in prepubertal gilts by elevated environmental temperature. Biol Reprod 1990;42:465-71. 